\title{
The Importance of Phonological Awareness Instruction in (Very) Young Second/Foreign Language Learners
}

\author{
Anita Sila \\ Faculty of Education, University of Primorska, Slovenia \\ anita.sila@pef.upr.si
}

\begin{abstract}
Phonological awareness (PA) instruction in early years plays an important role in helping children listen to their language's sound inventory, as well as in developing phonics, a sense of intonation, and rhythm. What is more, well-developed PA is a key element in the development of literacy skills in a second/foreign language. However, PA instruction is not a common practice in many second/foreign language classrooms. This paper therefore presents the results of several studies concerning systematic and explicit phonological awareness instruction in (very) young second/foreign language learners (aged under 7). Its main aim is to examine the effects of PA instruction as provided in different second/foreign languages (e.g. English, French, Italian) on the development of literacy skills in learners' first and/or second/foreign language. The findings show that children benefitted from early phonological awareness instruction in their first and/or second/foreign languages. It is hoped that our research will lead to an improved understanding of phonological awareness and that it will encourage teachers to find effective ways to apply it in practice. This would make it easier for children to learn to speak, read, and write in second/foreign languages in the future.
\end{abstract}

Keywords: oral skills, young learners' oracy, spoken language, phonological awareness instruction, teacher's language input

\section{Introduction}

In recent years there has been a growing interest in teaching reading and other literacy skills in children's first, second, and foreign languages. Literacy is usually understood as the ability to read and write, but the reality is more complex, as it involves using and applying strategies to various types of texts while gaining a comprehensive understanding of what has been read (Dell 2014). In order to help children become skilled readers and writers in any language, teachers should support (very) young learners' oral language proficiency, which sets a strong foundation for auditory and oral skills (Linse 2005). Effective pre-literacy and literacy instruction is therefore crucial in children's early education. Efforts to prevent reading problems should target not 
only oral language but also phonological awareness, as well as knowledge of the alphabet and print knowledge (National Research Council 1998; Whitehurst and Lonigan 2002). Oral language abilities affect the development of preliteracy skills such as phonological awareness and letter knowledge (Caravolas et al. 2012). Helman $(2009,117)$ explains this clearly: 'Each language or literacy interaction that children have is like a seed for their emerging literacy understanding. [...] The oral-language foundation that each student possesses is the soil on which emergent literacy develops. Informal and formal instruction in sounds and letters are like seeds planted that will sprout into understanding the alphabetic code.' By practicing language-rich activities at school/kindergarten and at home, emergent learners develop a more advanced understanding of print (Helman 2009). This process is especially crucial for foreign and second language learners, who experience the period of emergent literacy in a slightly different way. English language learners (ELLS), for example, who are learning oral English and its written features at the same time, are doing double duty - 'the phonemic and alphabetic seeds in English are being planted just as the soil of the English language is being prepared. Without a foundation of oral language, an understanding of text in that language will not flourish. So learning oral English and the written code become simultaneous goals for ELLs and require concerted planning efforts on the part of curriculum leaders and teachers' (Helman 2009).

In this paper, we focus on the importance of the development of phonological awareness (PA) skills in foreign/second language acquisition, as such skills comprise $a$ core prerequisite for early literacy development. Several studies have confirmed that the development of PA in learners' first and second languages is closely related and that it significantly predicts reading and writing performance in children learning to read in two alphabetic systems (Chiappe and Siegel 1999; Cisero and Royer 1995; Geva and Siegel 2000; Sun Alperin and Wang 2011). It is crucial to point out that the lack of phonemic awareness (the highest level of PA) is the most powerful determinant of the likelihood of failure to learn to read, also in a foreign language context (Moats and Foorman 1997; Adams 1990). What is more, poor PA is associated with poor auditory word acquisition for both $L_{1}$ and in $L 2$ (Bowey 1996; Elbro and Jesen 2005; de Jong, Seveke, and van Veen 2000; Hu 2003; Hu and Schuele 2005; Mayringer and Wimmer 2000). In addition, a close relationship between vocabulary knowledge and reading has been demonstrated by many empirical studies, which included English as both a first language and a second language (Stahl and Fairbanks 1986; Qian 2002; Nation 2001; Beck, McKeown, and Kucan 2002). 
This significant role of phonological awareness in developing L2 reading skills, as well as the lack of extant studies in this field, have led some researchers to examine the effects of phonological awareness instruction in helping second and foreign language learners acquire $L 2$ reading skills. This paper accordingly also reviews recent studies on the instruction of phonological awareness in (very) young second/foreign language learners (aged under 7). Explanations of phonological awareness and its development, along with recent findings from such studies, could be of potential help to second/foreign language educators who are challenged with teaching preliteracy and literacy skills at an early age (0-7).

\section{Metalinguistic Awareness}

Metalinguistic awareness is the ability to reflect upon and manipulate a language's structural features (Nagy and Anderson 1995). This awareness develops during preschool years and continues into adolescence and beyond. Metalinguistic awareness skills are related to the formal aspects of language: phonological, morphological, syntactic, and lexical awareness (Altman, Goldstein, and Armon Lotem 2018). The main skills covered by metalinguistic awareness include understanding of language and literacy functions or purposes, comprehending a text's visual-perceptual features and its structural characteristics (from the micro or word level to the macro or text level), procedural knowledge (from encoding to self-regulating metacognitive reading and writing strategies), metalanguage (language used to talk about language and literacy, including grammar of sentences and genres), and awareness of the symbolic nature of writing and its relationship to oral language (Chapman 2003).

People can be aware of their language at many different levels, from the automatic, virtually unconscious monitoring of their own speech, to the rapid language switching through languages by skilled translators and the detailed analytic work of linguists. The first signs of reflection upon language begin to appear at about age two. They are recognized as spontaneous corrections of one's own pronunciations, word forms, word order, and even choice of language in the case of bilinguals; questions about the right words, the right pronunciation, and the appropriate speech style; comments on the speech of others: their pronunciation, accent, and the language itself that is spoken; comments on and play with various linguistic units, segmenting words into syllables and sounds, making up etymologies, rhyming, and punning; judgments about linguistic structure and function, deciding what utterances mean, whether they are appropriate or polite, whether they are 
grammatical; questions about other languages and about language(s) in general (Clark 1978).

It is important to mention here that plurilingual experiences at an early age can influence the development of metalinguistic awareness skills, which are of key importance for language and literacy learning (Lourenço and Andrade 2013). Many studies (e.g. Yelland, Pollard, and Mercuri 1993; Bruck and Genesee 1995; Chen et al. 2004) have clearly shown that bilinguals possess more advanced metalinguistic awareness skills than monolinguals because they have to focus on the features of two languages. The positive impact of bilingualism has been confirmed in the sound and speech awareness of both first and second/foreign languages in preschool children and children in the first grades of school (Campbell and Sais 1995; Bruck and Genesee 1995; Chen et al. 2004; Marinova Todd, Zhao, and Bernhardt 2010; Rocha de Souza and Conceição Leite 2014).

There are certainly some features displayed by bilingual children that would hint at an advantage in PA, as comparing and contrasting between two languages makes them more attentive to the phonological form of words. In contrast to bilingual children, monolinguals tend to focus rather on the meaning of words and ignore other aspects. However, the advantage that bilingual children may have is not consistent across all levels of phonological awareness. Their relative performance seems to depend on the specific level of phonological awareness examined and the children's age. For bilingual as well as monolingual children, PA is also affected by the phonological structure of the language that children speak and the writing system they learn to read. Some studies (e.g. Marinova Todd, Zhao, and Bernhardt 2010; Bruck and Genesee 1995; Chen et al. 2004; Laurent and Martinot 2010) have confirmed some positive effects of bilingualism on the development of PA skills and some have not (e.g. Jackson, Holm, and Dodd 1998; Bialystok, Majumder, and Martin 2003). What is more, research findings indicate that monolingual children usually catch up with bilingual children after a while (Chen et al. 2004; Kuo and Anderson 2010). Thus, it cannot be asserted with certainty that bilingual and monolingual children have differently developed PA skills.

\section{Phonological Awareness Development}

Phonological awareness is the ability to notice, think about, or manipulate the sounds in language (Torgesen 1997), rather than just the meaning of the word. It is an understanding of the structure of spoken language - that it is made up of words, and words consist of syllables, rhymes, and sounds (Trehearne 2003). 
From birth through the end of first grade, children gradually develop their sensitivity to the phonological structure of language. Early accomplishments in phonological awareness include recognizing that sentences are composed of words, which words are composed of syllables, and that two words can rhyme. In the later pre-school years, children understand when two words share sounds in the beginning and final position of words, and usually by kindergarten they are able to combine sounds into words and segment words into their constituent sounds. In first grade, children acquire the ability to focus more intensely on the phonemic structure of words and syllables and to think about phonemes as distinct features of language (Justice et al. 2005). The continuum of PA skill development moves from the capacity to manipulate words, such as words in phrases and words within compounds (rain + bow $=$ rainbow), to the syllable level (sister $-/ \mathrm{sis} /=$ $/$ ter/), to onset-rime $(/ \mathrm{b} /+\mathrm{ird}=\mathrm{bird})$, and finally to phonemes $(/ \mathrm{m} /+/ \mathrm{o} /+/ \mathrm{p} /$ $=$ mop). This does not mean that children must master one level before moving to the next, as they can show incipient ability for more complex skills while still working toward the mastery of less complex ones (Phillips, ClancyMenchetti, and Lonigan 2008). This is probably also the reason for a slightly different explanation of the developmental sequence of some PA skills advanced by different authors. Chard and Dickson (1999), for example, list the development of alliteration awareness along with rhyme awareness, whereas Paulson and Moats (2010) list the development of alliteration awareness after children are able to recognize a word's initial sound. Nevertheless, all authors agree that the development of PA skills moves from less complex to more complex levels as it is summarized in table 1.

When children develop PA skills, it is important for educators to consider a range of tasks with varied difficulty, for example identity tasks (e.g. rhyme oddity, first sound matching), synthesis tasks (e.g. syllable or phoneme combining) or analysis tasks (e.g. word or syllable segmenting or deleting, phoneme counting tasks). Combining tasks typically are easier than analysis tasks and tasks requiring production are more challenging than recognition tasks. In addition, tasks supported by visual props or tasks that use multiplechoice items are simpler for children than those that require more memory or verbal production (Phillips, Clancy-Menchetti, and Lonigan 2008). Some other dimensions of task complexity in phonological awareness include word length (shorter words are easier than longer words), size of phonological unit (onset-rime manipulation is easier than phoneme manipulation), consonant clusters and the articulatory features of words (identifying continuous sounds - sonorants and fricatives are easier than stops and affricates and clusters), and identifying phonemes in words by position (beginning, 
Table 1 The Development of PA Skills from Less Complex to More Complex Levels

\begin{tabular}{|c|c|c|}
\hline \multicolumn{2}{|l|}{ Level } & \multirow{2}{*}{$\begin{array}{l}\text { Activities } \\
\text { Distinguishing between long and short words, segment- } \\
\text { ing sentences into words, counting words in a sentence, } \\
\text { forming a compound word (e.g. Dog + house = dog- } \\
\text { house), removing one word from a compound word and } \\
\text { saying what remains (e.g. Notebook - note = book). }\end{array}$} \\
\hline $\begin{array}{l}\text { Less complex } \\
\text { levels }\end{array}$ & Word & \\
\hline & Rhyme & $\begin{array}{l}\text { Identifying rhymes, odd-one-out rhymes, matching } \\
\text { rhymes, producing rhymes. }\end{array}$ \\
\hline & Syllable & $\begin{array}{l}\text { Combining syllables into words, segmenting words into } \\
\text { syllables, deleting syllables. }\end{array}$ \\
\hline $\begin{array}{l}\text { Beginning of } \\
\text { phonemic } \\
\text { awareness }\end{array}$ & Onset-rime & $\begin{array}{l}\text { Combining onsets and rimes into words, segmenting } \\
\text { words into onsets and rimes, producing words from giv- } \\
\text { en onsets/rimes. }\end{array}$ \\
\hline $\begin{array}{l}\text { More complex } \\
\text { levels }\end{array}$ & Sound & $\begin{array}{l}\text { Distinguishing between similar initial and final sounds, } \\
\text { identifying and producing alliteration, identifying first, } \\
\text { final, and middle sound in a word, identifying the place } \\
\text { of the sound in a word, producing words with given ini- } \\
\text { tial and final sounds, combining sounds into words, seg- } \\
\text { menting words into sounds, manipulating sounds (addi- } \\
\text { tion, deletion, substitution). }\end{array}$ \\
\hline
\end{tabular}

Notes Adapted from Chard and Dickson (1999), Paulson and Moats (2010), Pečjak (1999), Schuele and Boudreau (2008), Trehearne (2003), Yopp and Yopp (2000), Phillips, ClancyMenchetti, and Lonigan (2008).

ending, middle - the latter is the most difficult) (Barrus Smith, Simmons, and Kameenui 1995).

Children first learn to identify or manipulate the initial consonant in a cluster onset (e.g. crest) or the final consonant in a cluster coda (e.g. crest) and then to identify or manipulate the medial consonants (e.g. crest) (Anthony and Francis 2005). Articulatory factors also contribute to a word's linguistic complexity. Children develop sensitivity to differences in the placement of articulation, the location along the vocal tract where the tract is occluded or narrowed, before developing sensitivity to differences in phoneme voicing (Treiman et al. 1998). Recent scholarly attention to segmental phonetics signals the importance of articulation, not the imitation of sounds, as a key learning impulse in acquisition processes (Anumanchipalli, Chartier, and Chang 2019).

\section{Language-Related Differences in PA Development}

Although the developmental sequence of phonological awareness from large to small sound units is universal across languages, it has been found 
that certain characteristics of individual spoken (e.g. saliency and complexity of word structures, phoneme position, and articulatory factors) and written languages influence the rate of normal development and levels of phonological awareness that are normally achieved (Anthony and Francis 2005). According to Ziegler and Goswami (2005), this could simply reflect the lack of cross-language matching for factors like vocabulary acquisition and teaching practices in kindergarten. However, systematic language-related differences and the fact that early forms of phonological awareness develop prior to literacy instruction suggest that experiences with oral language interactions play an important role in the development of phonological awareness (Anthony and Francis 2005).

A number of studies have been carried out to uncover the characteristics of oral language that foster the development of particular phonological awareness skills. Durgunoğlu and Öney (2002) point out that children who learn Turkish, Greek, and Italian, all languages with a simple syllable structure and relatively limited vowel repertoires, show high levels of syllable awareness prior to literacy. In contrast, children who learn French and English as languages with quite complex syllable structures and many consonant clusters, as well as larger vowel repertoires, develop lower levels of syllable awareness prior to literacy. What is more, the saliency and complexity of onsets in spoken language may influence the development of onset awareness and phoneme awareness (Anthony and Francis 2005). Caravolas and Bruck (1993) found that preliterate English-speaking children were better than preliterate Czech-speaking children at isolating onsets with one consonant, whereas Czech-speaking children were more aware of individual phonemes within clusters than English-speaking children. According to Anthony and Francis (2005), these findings correspond to the phonological characteristics of the two languages: Czech has more and different cluster onsets (258) than English (31).

Moreover, vowel and consonant harmony also influence the development of phoneme awareness. For example, kindergarten children who speak Turkish constantly monitor and manipulate the phonemes in roots, prefixes, and suffixes in order to achieve vowel and consonant harmony. This may force them to become sensitive to phonemes. Thus, kindergarten children who speak Turkish are better at deleting the final phoneme from words than kindergarten children who speak English, which does not require vowel harmony (Durgunoğlu and Öney 1999). In addition, children who speak languages with more rime neighbours (e.g. the English words bright, kite, and height are phonological rime neighbours because they share a similar rime) 
than body neighbours (e.g. words like cat, cab, and calf that share a similar onset and vowel combination, called a body) develop onset-rime awareness prior to body-coda awareness (the coda usually being the terminal consonant or consonant cluster). On the one hand, English, French, Dutch, and German children learn to segment a consonant-vowel-consonant (CVC) syllable into onset and rime (C-VC) before they learn to segment a CVC syllable into body and coda (CV-C) (Ziegler and Goswami 2005; Anthony and Francis 2005). Young Japanese children, on the other hand, may develop body-coda awareness before onset-rime awareness (Inagaki, Hatano, and Otake 2000).

Finally, a language's orthographic transparency also influences the rate at which its speakers develop phonological awareness. Children who learn to read an alphabetic language with a transparent orthography (consistent spelling-to-sound relations and consistent sound-to-spelling relations) develop phoneme awareness more quickly than children with less transparent orthography do. For example, German children in their first year of schooling develop phoneme awareness more quickly than English children do. In addition, children can have difficulties with counting phonemes in a word if the number of letters and phonemes differ, as well as with judging whether two words rhyme if the words are spelled differently (e.g. rye-tie) (Anthony and Francis 2005).

\section{The Importance of Phonological Awareness Development in a Foreign/Second Language}

Some children develop PA skills fairly easily within a stimulating classroom environment, while others need more explicit and systematic instruction that consciously and deliberately focuses on PA (Trehearne 2003). Classroombased instruction in phonological awareness should be provided to all preschool and kindergarten children in order to establish a foundation of ability on which to build the skills of decoding and spelling in the early elementary grades (Schuele and Boudreau 2008). Children (approximately 20\%) who fail to acquire an adequate foundation of PA, even when good classroom instruction is provided, (Torgesen 2000) need explicit corrective help with phonological awareness in late kindergarten or early first grade (Schuele and Boudreau 2008). There are several key elements to providing systematic and explicit instruction, including instructional sequencing, modeling, and explaining the task, scaffolding, and providing corrective feedback (Phillips, Clancy-Menchetti, and Lonigan 2008; for more see e.g. Schuele and Boudreau 2008).

As PA skills transfer from one language to another (Cardenas Hagan, Carl- 
son, and Pollard Durodola 2007; Dickinson et al. 2004) it is very important to help children develop good phonological awareness in their first language. Native language proficiency $\left(L_{1}\right)$ in reading and writing seems to be the number-one predictor of overall skill in a second language (L2). However, the speed of native language learning is also a significant predictor of L2 skill (Sparks et al. 2006). Although PA transfers from one language to another, children should learn to distinguish between the sounds in their L1 and $L 2$, otherwise they risk difficulties with associating sounds with written letters or groups of letters - phonics. Students may not be able to 'hear' or produce a new sound in a second language (probably because that sound was not a part of the student's native language), e.g. a Slovenian speaker would pronounce an English $/ \Theta /$ as /t/, a Japanese speaker would pronounce an English /// as / $r /$, a French speaker would pronounce an English $/ \Theta /$ as /s/ or /z/, a Spanish speaker would pronounce an English /v/ as /b/. These sounds may not be perceived as being different by the speaker because they do not discriminate between the two and can cause special problems for learners.

Instruction in systematic and explicit phonological awareness is, therefore, also of great importance in second/foreign language learning at an early age in order to achieve functional bilingual or multilingual literacy. Children who acquire a second language from birth or before the age of three are immediately aware of the sound characteristics in both languages. They develop dual vocabulary and a certain degree of comprehension in both languages. Bilingual children must become familiar with writing systems in both languages during school years (they must learn about similarities and differences in the sound and writing systems). Even children who learn another language after the age of six need to learn to distinguish between the sounds in their $L_{1}$ and $L_{2}$ in order to learn the correspondence between these sounds and the spelling patterns (graphemes) that represent them. After the age of six, though, mastering the pronunciation of certain sounds becomes more difficult. A child might also encounter a new writing system. Some languages do not use the alphabetic system, but syllable or iconographic and logographic systems instead (Colja 2013). Phonological skills are important in learning to read in any language system.

In alphabetic writing systems, there are transparent and opaque orthographies. In transparent orthography (e.g. Spanish, Italian), there are graphemes which map almost one-to-one onto phonemes, while in opaque orthography (e.g. French, English), there are graphemes that have many phonetic interpretations or phonemes that have many graphemic interpretations (Du- 
lude 2012). Research has shown that transparent orthographies are more easily acquired than complex and opaque orthographies (e.g. Aro and Wimmer 2003; Seymour, Aro, and Erskine 2003). For example, children learning to read in English may encounter more challenges in decoding and building a sight vocabulary than children learning to read in a relatively transparent orthography like Spanish (Spencer 2007).

In addition, when planning instruction, educators should also consider language interferences (transfer). The term transfer in the context of nonnative language acquisition or use broadly refers to the influence of the learner's native language. Language transfer can be negative or positive. Negative transfer or interference occurs when the influence of the native language leads to errors in the acquisition or use of a target language, while positive transfer or facilitation occurs when the influence of the native language leads to immediate or rapid acquisition or use of the target language. Negative transfer, which manifests itself in different linguistic domains, including phonetics and phonology (or pronunciation), morphology and syntax, vocabulary, and pragmatics, poses challenges to teaching and learning (BardoviHarlig and Sprouse 2018). For example, in the field of phonetics and phonology, Slovenian English students acquiring English as a foreign language often have problems with a distinction between long and short vowels (e.g. distinction between 'to leave' and 'to live') (Bratož and Kocbek 2015). What is more, in vocabulary acquisition, positive transfer may account for the immediate recognition and acquisition of words with similar or identical pronunciation in both first and second/foreign languages. However, words known as false friends (ones that look and/or sound alike in the native and target languages but have different meanings, e.g. English parent and French parent, 'relative'; English become and German bekommen, 'to receive' (Bardovi-Harlig and Sprouse 2018); English scholar and Slovenian šolar, 'pupil'; in English biscuit and in Slovenian biskvit, 'sponge cake' (Bratož and Kocbek 2015)) are also likely to lead to errors (Bardovi-Harlig and Sprouse 2018).

All this means that the similarities between languages can present an obstacle. If these errors are not given sufficient attention in teaching, they can remain permanent. Moreover, interferences are reproducible and the most noticeable occur at the level of phonetics and phonology. Thus, they are one of the major causes of retaining a 'foreign accent' (Sabo 2016). It is therefore particularly important that teachers of (very) young language learners give special attention to listening activities, and activities of sound differentiation, as well as pronunciation of sounds that are not present in the first language (in Slovenian for example, the sound $/ \Theta /$ in the word three), or phonetically 
similar sounds (e.g. /s/ and /z/, /// and /r/, /d/ and /t/) (Skela, Sešek, and Dagarin Fojkar 2009). This can be done by demonstrating and reinforcing the correct production of a specific sound in small groups through games, nonreading activities, and work with a puppet. For example, children can match pictures of familiar English words that have the same beginning, middle, or ending sound or they can listen to the initial/middle/ending sound and find the corresponding picture.

\section{Research Review on Systematic PA Instruction in a Foreign/Second Language}

PA is significantly related to reading in both first and second/foreign languages (Chiappe, Siegel, and Wade Woolley 2002; Gottardo et al. 2001; Lesaux and Siegel 2003). This fact and the lack of extant studies in this field have led some researchers to examine the effects of phonological awareness instruction in helping ESL and EFL children acquire $L 2$ reading skills. Some of the studies below were conducted with preschool children and some of them with primary school children.

\section{Studies with Preschool Children}

Giambo and McKinney (2012) conducted a study in order to determine whether phonological awareness instruction promoted oral English proficiency more than a story-reading condition for Spanish-speaking kindergarten children, most of whom had limited English proficiency. Their second aim was to determine the extent to which change in English proficiency over the course of the instruction period could be attributed to changes in phonological awareness. Pre- and post-test measures included tests of oral English proficiency, receptive English vocabulary, and phonological awareness. The results of both groups showed a significant change in oral English proficiency over pre-test scores. However, an analysis of covariance indicated that the phonological awareness group showed greater change than did the story-reading group. Multiple regression analyses were carried out with measures of sound discrimination, short-term memory, and change in vocabulary and phonological awareness in the predictive model. The findings revealed that changes in phonological awareness variables were the only significant predictors of change in oral English proficiency. These results confirmed that phonological awareness instruction promotes oral English proficiency for Spanish-speaking kindergarten children. According to the authors, a balanced reading program for Spanish-speaking kindergarten children with limited English proficiency should therefore also include phono- 
logical awareness instruction in order to help children develop oral English proficiency.

Yeung, Siegel, and Chan (2013) explored the effects of 12 weeks of languageenriched phonological awareness instruction on 76 young Hong Kong children who were learning English as a second language. Their mean age was 5.14 ( $S D=0.23$; range $=4$ years, 9 months to 5 years, 9 months). There were 38 children in the experimental group (EG) and 38 in the control group (CG). Children in the $E G$ received PA instruction embedded in vocabulary learning activities or comparison instruction, which consisted of vocabulary learning and writing tasks but no direct instruction in phonological awareness skills. Teachers were given the targeted word list of the language-enriched phonological awareness instruction and were asked to teach the words, while children in the CG were given typical Hong Kong kindergarten English instruction. Cantonese is used as the medium of instruction and English is regarded as a school subject. Children have 2-3 English lessons per week, each of approximately 20-30 min, with Native English Teachers (NETs). They also do English and Chinese writing (copying) every day (20-30 min per day), instructed by the class teachers. There is no systematic phonics teaching provided. Children in both groups went through twenty-four 30-minute sessions over a period of 12 weeks. The two instructions were comparable in terms of learning time and the targeted vocabulary. Children were tested on receptive and expressive vocabulary, phonological awareness at the syllable, rhyme and phoneme levels, reading, and spelling in English before and after the program implementation. The results indicated that children who received the PA instruction performed significantly better than children in the CG on English word reading, spelling, PA at all levels and expressive vocabulary on the post-test when age, general intelligence and the pre-test scores were controlled statistically. That means that PA instruction embedded in vocabulary learning activities might be beneficial to kindergarteners learning English as a second language.

Bing, Hui, and Bingxia (2013) carried out a longitudinal study following an English PA training program, aiming to investigate the long-term effect of the training on young English learners' subsequent literacy acquisition in China. Eighty primary school children from two intact classes in first grade participated in the study. Among them, 44 children in the experimental group received 10 weeks' PA training, while the remaining 36 children in the control group did not. All children participated in the tests, which were conducted at two time points - 6 months and 12 months after the training sessions respectively. The training program was designed with reference to Schuele and 
Boudreau's study (2008). It began in late September 2010, and lasted for 30 minutes each time, once per week, 10 weeks in total, and was carried out by one of the researchers. Both tests examined participants' early English reading and spelling (Test 2 also investigated the participants' reading comprehension and PA). The results of the study showed that the experimental group performed better than the control group on every literacy sub-skill test in both tests conducted after the training, showing significantly better performance in early English reading and spelling than the control group. This means that there is a long-term training effect on participants' literacy acquisition. In addition, the study also suggests that PA is closely related to English literacy skills, and that the initial phoneme deletion is likely the most powerful predictor of children's early English reading and spelling.

Sila (2018) conducted a study with preschool children (5-6 years old) in order to explore the effects of explicit and systematic PA instruction in English on the development of PA in English (foreign language) and Slovene (first language). Over 3 years there were 2 periods of instruction conducted by the researcher and 1 by other practitioners. The first instruction period (January 2014-June 2014) lasted 40 hours (each for 45 minutes), twice a week. It included 15 children. Before and after the instruction period all children took a test on phonological awareness skills (from less to more complex; the first test was in Slovene, the second was in both languages). The results showed that children improved their skills at all levels (word, rhyme, syllable, onsetrime, sound). The biggest improvement was in recognizing initial sounds in both languages, whereas the smallest improvement was in the production of words (with a given ending sound) in Slovene and the production of words (with a given initial sound) in English, as well as in distinguishing between short and long words, and in segmenting syllables. Children were more successful at producing rhymes, words (with a given initial sound) and alliteration, segmenting sentences into words, and segmenting words into syllables in English, whereas in Slovene they had better results in distinguishing between short and long words. The second instruction period (January 2015June 2015) also lasted 40 hours (each for 45 minutes), twice a week and included 15 children in the experimental group and 15 children in the control group. This time the test was conducted only in Slovene (at the beginning and the end of instruction) and it showed similar results. Children improved skills at all levels (word, rhyme, syllable, onset-rime, sound). Their highest improvement was in recognizing final sounds, whereas the lowest improvement was in segmenting words into constituent sounds. The third instruction period was administered by practitioners (a teacher of English, preschool teacher 
and assistant) (March 2016-May 2016). It lasted 40 hours (each for 45 minutes), twice a week (once a week in Slovene and once a week in English). It included 6 children. The results of the PA test in Slovene (before and after the intervention) also showed that children improved skills at all levels (word, rhyme, syllable, onset-rime, sound); the biggest improvement was in distinguishing between long and short words, producing rhymes, segmenting words into sounds, manipulating sounds, and recognizing final sounds.

\section{Studies with Primary School Children}

Zorman (2007) carried out a study with 140 primary school children learning Italian as a second language in schools with Slovene as their language of instruction. They began their schooling in the 2001-2 school year and attended the fourth grade in the 2004-5 school year. The study was a pedagogical experiment with two comparable groups (control and experimental). Children in the experimental group were given systematic literacy instruction in Italian: phonology, phonological awareness development, and systematic learning of phoneme-grapheme correspondences with a particular stress on phonemes, graphemes, and phoneme-grapheme correspondences that differ in Italian with respect to Slovene. The effects of the introduction of systematic literacy instruction were measured by testing phonological awareness and dictation. Study results have shown that children in the experimental group achieved significantly better results on all contents and levels tested. This confirms that children learn to read and write significantly better when they receive systematic literacy instruction in a second/foreign language.

Wise and Chen (2010) in their study analysed the impact of phonological awareness instruction on the reading achievement of 29 at-risk Grade 1 readers from diverse linguistic backgrounds enrolled in an early French immersion program. At-risk readers were identified by their text-reading performance and phonological awareness test scores. They also received 20 weeks of phonological awareness training in small groups. Instruction was initially given in English and then switched to French (when students had acquired a foundation in the language). Significant progress was found in the phonological awareness skills of the treatment group. Results also showed that the end-of-year French reading levels of the experimental group were superior to those of the comparison group. These findings show that phonologically based instruction can effectively address phonological awareness deficits and facilitate French reading acquisition for early immersion students who are considered to be at risk of developing later reading difficulties. 
Al Tamimi (2012) investigated the effectiveness of explicit phonological awareness instruction in contrast with formal classroom instruction on developing phonological awareness skills for 60 Jordanian EFL second-graders (average age $=7.1$ ) at a governmental school. Their native language is Arabic, and English has been taught to them as a foreign language. In addition, almost all the test subjects had previously had the chance to learn some English at kindergarten. A phonological training program focused on five phonological awareness skills: segmentation, isolation, deletion, substitution and combining, and their respective sub-skills. On measures of Robertson and Salter's (1997) Phonological Awareness Test (PAT), the experimental group that underwent fifteen 40-minute phonological awareness sessions outperformed the control group in deletion, substitution, and combining skills; the control group continued to receive formal classroom instruction. These findings are also consistent with previous research, favouring explicit phonological awareness instruction, thus giving less credit to formal classroom instruction.

Le Roux et al. (2017) wanted to determine the effects of instruction in vowel perception and production on phonemic awareness and literacy skills of Setswana first language ( $\left.\mathrm{L}_{1}\right)$ learners. These learners are English second language (EL2) learners in Grade 3 and aged between 8 and 10 years old. These learners were exposed to ELoLT for 3-4 years, and basic literacy skills should have been established at this stage. The EL1 group included 12 South African English L1 speakers attending an English medium school in Pretoria. This group was seen as the 'norm' and did not receive additional instruction. The EL2 group included 15 EL2 (Setswana L1 speaking) learners, attending two English medium primary schools in the Moot (Pretoria). These participants received additional input concerning the English vowel system by final-year EL1 Speech-Language Therapy (SLT) students. The control group included $15 \mathrm{EL} 2$ (Setswana L1 speaking) learners who were selected from the same schools as participants in the EL2 group and did not receive additional instruction. Their study, which employed a quasi-experimental, pre-test-post-test design, revealed that PA instruction improved the literacy skills of EL2. These results suggest, according to the authors, that PA skills should be a crucial part of the literacy curriculum in South Africa.

Murakami and Cheang (2017) (programme year 1) gave direct structural instructions focused on rhyming and syllable awareness to 101 students in the 2nd grade at Japanese public elementary schools. They designed the program very carefully so that students were not only aware of English phonological units but also of their manipulation through several activities. The in- 
structions were given 6 times in total between June and November 2015 by Cheang, the co-author of the present study, who has knowledge and experience in teaching phonological awareness and phonics. Authors assessed the students' general level of phonological awareness before and after the instructions were given in order to verify their effects. The result of the posttest showed remarkable progress on both the rhyming and syllable tests. The findings also showed that the students had some degree of difficulty in recognizing medial vowels, as well as in separating initial consonants from medial vowels, which are co-articulated in speech.

In March 2017, Murakami (2017) carried out another study in order to assess the students' general level of English phonological awareness, and to verify the effectiveness of the previously provided instruction in syllable awareness. This time 80 students in the 3 rd grade participated in the English phonological awareness assessment, Test 3 (they took Test 1 and Test 2 during program year 1). In program year 2 (2016), the students did not receive any phonological awareness instruction, except for a one-time 15-minute syllable segmentation game in November. Test 3 was conducted at the very end of program year 2, after a 15-month period in which no instruction was provided. The results of Test 3 showed improvement in almost all tasks. In addition, the scores of at-risk students ( $9 \%$ of the lowest) decreased in Test 3 as compared with Test 2 . The results of their study thus also indicate that phonological awareness can be developed through instruction, and thereupon retained and further enhanced. The authors suggest that individual differences in the teaching methods and conditions should be taken into consideration.

To sum up, studies confirmed that explicit and systematic PA instruction in foreign languages, embedded in vocabulary learning activities, helps children improve PA skills at all levels and develop oral foreign language proficiency, reading, spelling and writing skills in both languages. This also applies to early immersion students who are considered to be at risk of developing later reading difficulties. In addition, as there is a long-term training effect on participants' literacy acquisition, PA should be thoughtfully developed in the educational process and not left to the natural or intuitive development of children. Bing, Hui, and Bingxia (2013) also advise that instruction programmes for foreign language learners should last longer than those for native speakers. What is more, in order to develop PA skills in a foreign language successfully, teachers should have highly developed language skills in native and foreign/second languages, and they should understand the pro- 
cess of developing early literacy and, in this context, PA skills. They should be familiar with the similarities and differences between developing literacy in both languages. Moreover, they should know the characteristics of the target language and the differences between languages (as regards phonics and writing systems). They should understand the development of language competencies and the process of acquiring and learning first and foreign/second languages (Sila 2018).

Overall, early PA instruction is beneficial to all children, but especially to foreign/second language learners. Thus, children develop oral language proficiency and early literacy skills in both languages.

As the studies in this review focused on particular language groups, the findings cannot be generalized beyond the particular language combinations studied.

\section{Conclusion}

This paper presents an overview of the findings in research focusing on phonological awareness instruction administered to (very) young language learners in foreign language classrooms. Several studies have shown that systematic and explicit instruction of PA in foreign languages can improve PA skills in the first and second (foreign) language. As PA instruction in foreign languages improves spelling, reading, vocabulary, rapid naming, PA skills, listening and reading comprehension, communication, and phonics skills, it is important to integrate PA instruction in second/foreign language learning at an early age. This imperative is even greater in multilingual classroom contexts as children come from different language backgrounds and need to learn to distinguish between the sounds in their $L 1$ and $L 2$, in order to learn how to read and write. Thus, it would be most advisable to develop PA skills in both languages.

Regarding future research, we believe the evidence from existing studies is so clear that future studies should be confined to longitudinal and training studies. There is no doubt that explicit phonological awareness instruction has a positive impact in developing literacy in first and second/foreign languages. However, future studies should concentrate on how such instruction can be most effectively delivered in multilingual settings (in kindergarten) and what other skills should be trained in order to help children from different language backgrounds reduce the possibility of reading and writing difficulties at school entry time.

In conclusion, raising the awareness of teachers, educators, and parents about the importance of developing PA in both languages at an early age 
can facilitate children's process of acquiring literacy skills in first and second/foreign languages.

\section{References}

Adams, Marilyn Jager. 1990. Beginning to Read: Thinking and Learning about Print. Cambridge, MA: MIT Press.

Al Tamimi, Yasser. 2012. 'Relevance of Phonological Awareness Intervention to a Jordanian EFL Classroom.' Arab World Geographer 3 (2): 117-47.

Altman, Carmit, Tamara Goldstein, and Sharon Armon Lotem. 2018. 'Vocabulary, Metalinguistic Awareness and Language Dominance among Bilingual Preschool Children.' Frontiers in Psychology 9. https://doi.org./10.3389/ fpsyg.2018.01953

Anthony, Jason L., and David J. Francis. 2005. 'Development of Phonological Awareness.' American Psychological Society 14 (5): 255-9.

Anumanchipalli, Gopala K., Josh Chartier, and Edward F. Chang. 2019. 'Speech Synthesis from Neural Decoding of Spoken Sentences.' Nature 568:493-8.

Aro, Mikko, and Heinz Wimmer. 2003. 'Learning to Read: English in Comparison to Six More Regular Orthographies.' Applied Psycholinguistics 24 (4): 621-35.

Bardovi-Harlig, Kathleen, and Rex A. Sprouse. 2018. 'Negative versus Positive Transfer.' In The TESOL Encyclopedia of English Language Teaching, edited by Joh I. Liontas, 1-6. Hoboken: Wiley.

Barrus Smith, Sylvia, Deborah C. Simmons, and Edward J. Kameenui. 1995. 'Phonological Awareness: Curricular and Instructional Implications for Diverse Learners: Review of Converging Evidence.' Technical Report 22, National Center to Improve the Tools of Educators, Eugene, OR.

Beck, Isabel. L., Margaret G. McKeown, and Linda Kucan. 2002. Bringing Words to Life: Robust Vocabulary Instruction. New York: Guilford Press.

Bialystok, Ellen, Shilpi Majumder, and Michelle M. Martin. 2003. 'Developing Phonological Awareness: Is There a Bilingual Advantage?' Applied Psycholinguistics 24 (1): 27-44.

Bing, Sun, Zhou Hui, and Zhu Bingxia. 2013. 'Effects of English Phonological Awareness Training on Chinese Child EFL Learners' Literacy Development.' Canadian Social Science 9 (1), 56-64.

Bowey, Judith A. 1996. 'On the Association Between Phonological Memory and Receptive Vocabulary in Five-Year-Olds.' Journal of Experimental Child Psychology 63:44-78.

Bratož, Silva, and Alenka Kocbek. 2015. 'Novi pogledi na vlogo prevajanja pri poučevanju tujega jezika.' In Aktivnosti učencev $v$ učnem procesu, edited by Dejan Hozjan, 223-35. Koper: Annales.

Bruck, Maggie, and Fred Genesee. 1995. 'Phonological Awareness in Young Second Language Learners.' Journal of Child Language 22 (2): 307-24.

Campbell, Ruth, and Efisia Sais. 1995. 'Accelerated Metalinguistic (Phonologi- 
cal) Awareness in Bilingual Children.' British Journal of Developmental Psychology 13 (1): 61-8.

Caravolas, Marketa, and Maggie Bruck. 1993. 'The Effect of Oral and Written Language Input on Children's Phonological Awareness: A Cross-Linguistic Study.' Journal of Experimental Child Psychology 55 (1): 1-30.

Caravolas, Marketa, Arne Lervåg, Petroula Mousikou, Corina Efrim, Miroslav Litavský, Eduardo Onochie-Quintanilla, Naymé Salas et al. 2012. 'Common Patterns of Prediction of Literacy Development in Different Alphabetic Orthographies.' Psychological Science 23 (6): 678-86.

Cardenas Hagan, Elsa, Coleen D. Carlson, and Sharolyn D. Pollard Durodola. 2007. 'The Crosslinguistic Transfer of Early Literacy Skills: The Role of Initial L1 and L2 Skills and Language of Instruction.' Language, Speech, and Hearing Services in Schools 38 (3): 249-59.

Chapman, Marilyn. 2003. 'Phonemic Awareness: Clarifying What We Know.' Literacy Teaching and Learning 7 (1-2): 91-114.

Chard, David J., and Shirley V. Dickson. 1999. 'Phonological Awareness: Instructional and Assessment Guidelines.' Intervention in School and Clinic 34 (5): 261-70.

Chen, Xi, Richard C. Anderson, Wenling Li, Meiling Hao, Xinchun Wu, and Hua Shu. 2004. 'Phonological Awareness of Bilingual and Monolingual Chinese Children.' Journal of Educational Psychology 96 (1): 142-51.

Chiappe, Penny, and Linda Siegel. 1999. 'Phonological Awareness and Reading Acquisition in English- and Punjabi-Speaking Canadian Children.' Journal of Educational Psychology 91 (1): 20-8.

Chiappe, Penny, Linda Siegel, and Lesly Wade Woolley. 2002. 'Linguistic Diversity and the Development of Reading Skills: A Longitudinal Study.' Scientific Studies of Reading 6 (4): 369-400.

Cisero, Cheryl A., and James M. Royer. 1995. 'The Development and CrossLanguage Transfer of Phonological Awareness.' Contemporary Educational Psychology 20 (3): 275-303.

Clark, Eve V. (1978). 'Awareness of Language: Some Evidence from What Children Say and Do.' In The Child's Conception of Language, edited by Anne Sinclair, Robert J. Jarvella, and Willem J. M. Levelt, 17-44. Berlin and New York: Springer-Verlag.

Colja, Tanja. 2013. Porajajoča se pismenost v dvojezičnem okolju: primer otrok, ki obiskujejo vrtce s slovenskim učnim jezikom v Italiji in dvojezični vrtec $v$ Špetru. Trieste: Ciljno začasno združenje 'Jezik - Lingua.'

de Jong, Peter F., Marie- José Seveke, and Marjo van Veen. 2000. 'Phonological Sensitivity and the Acquisition of New Words in Children.' Journal of Experimental Child Psychology 76 (4): 275-301.

Dell, Jamie L. 2014. 'Literacy Instruction in Early Childhood Education: Ohio's Third Grade Reading Guarantee.' Honors Thesis, University of Dayton. 
Dickinson, David, Allyssa McCabe, Nancy Clark Chiarelli, and Anne Wolf. 2004. 'Cross-Language Transfer of Phonological Awareness in Low-Income Spanish and English Bilingual Preschool Children.' Applied Psycholinguistics 25 (3): 323-47.

Dulude, Laura. 2012. 'Writing Systems, Phonemic Awareness, and Bilingualism: Cross-Linguistic Issues in Dyslexia.' Indiana University Undergraduate Journal of Cognitive Science 7:22-30.

Durgunoğlu, Aydı Yücesan, and Banu Öney. 1999. 'A Cross-Linguistic Comparison of Phonological Awareness and Word Recognition.' Reading and Writing: An Interdisciplinary Journal 11 (4): 281-99.

- 2002. 'Phonological Awareness in Literacy Acquisition: It's Not Only for Children.' Scientific Studies of Reading 6 (3): 245-66.

Elbro, Carsten, and Mette Nygaard Jensen. 2005. 'Quality of Phonological Representations, Verbal Learning, and Phoneme Awareness in Dyslexic and Normal Readers.' Scandinavian Journal of Psychology 46 (4): 375-84.

Geva, Esther, and Linda Siegel. 2000. 'Orthographic and Cognitive Factors in the Concurrent Development of Basic Reading Skills in Two Languages.' Reading and Writing 12 (1-2): 1-30.

Giambo, Debra, and James D. McKinney. 2012. 'The Effects of a Phonological Awareness Intervention on the Oral English Proficiency of SpanishSpeaking Kindergarten Children.' TESOL Quarterly 38 (1): 95-117.

Gottardo, Alexandra, Bernice Yan, Linda S. Siegel, and Lesly Wade-Woolley. 2001. 'Factors Related to English Reading Performance in Children with Chinese as a First Language: More Evidence of Cross-Language Transfer of Phonological Processing.' Journal of Educational Psychology 93 (3): 530-42.

Helman, Lori. 2009. 'Emergent Literacy: Planting the Seeds for Accomplished Reading and Writing: Research-Based Instruction in Grades K-6.' In Literacy Development with English Learners, edited by Lori Helman, 117-37. New York: The Guilford Press.

$\mathrm{Hu}$, Chieh-Fang. 2003. 'Phonological Memory, Phonological Awareness, and Foreign Language Word Learning.' Language Learning 53 (3): 429-62.

$\mathrm{Hu}$, Chieh-Fang, and Melanie Schuele. 2005. 'Learning Nonnative Names: The Effect of Poor Native Phonological Awareness.' Applied Psycholinguistics 26 (3): 343-62.

Inagaki, Kayoko, Giyoo Hatano, and Takashi Otake. 2019. 'The Effect of Kana Literacy Acquisition on the Speech Segmentation Unit Used by Japanese Young Children.' Journal of Experimental Child Psychology 75 (1): 70-91.

Jackson, Nicola, Alison Holm, and Barbara Dodd. 1998. 'Phonological Awareness and Spelling Abilities of Cantonese-English Bilingual Children.' Asia Pacific Journal of Speech, Language and Hearing 3 (2): 79-96.

Justice, Laura M., Khara L. Pence, Angela R. Beckman, Lori E. Skibbe, and Alice K. Wiggins. 2005. Scaffolding with Storybooks: A Guide for Enhancing Young 
Children's Language and Literacy Achievement. Newark, DE: International Reading Association.

Kuo, Li-Jen, and Richard C. Anderson. 2010. 'Beyond Cross-Language Transfer: Reconceptualizing the Impact of Early Bilingualism on Phonological Awareness.' Scientific Studies of Reading 14 (4): 365-85.

Laurent, Angélique, and Clara Martinot. 2010. 'Bilingualism and Phonological Awareness: The Case of Bilingual (French-Occitan) Children.' Reading and Writing 23 (3-4): 435-52.

Le Roux, Maria, Salome Geertsema, Heila Jordaan, and Danie Prinsloo. 2017. 'Phonemic Awareness of English Second Language Learners.' The South African Journal of Communication Disorders 64 (1): e1-e9.

Lesaux, Nonie K., and Linda S. Siegel. 2003. 'The Development of Reading in Children Who Speak English as a Second Language (ESL).' Developmental Psychology 39 (6): 1005-19.

Linse, Caroline. T. 2005. Practical English Language Teaching: Young Learners. New York: McGraw-Hill.

Lourenço, Monica, and Isabel Ana Andrade. 2013. 'Promoting Phonological Awareness in Pre-primary Education: Possibilities of the "Awakening to Languages" Approach.' Language Awareness 23 (4): 304-18.

Marinova Todd, Stefka H., Jing Zhao, and Barbara May Berhardt. 2010. 'Phonological Awareness Skills in the Two Languages of Mandarin-English Bilingual Children.' Clinical Linguistics and Phonetics 24 (4-5): 387-400.

Mayringer, Heinz, and Heinz Wimmer. 2000. 'Pseudoname Learning by Germanspeaking Children with Dyslexia: Evidence for a Phonological Learning Deficit.' Journal of Experimental Child Psychology 75 (2): 116-33.

Moats, Louisa C., and Barbara R. Foorman. 1997. 'Introduction to the Special Issue of SSR: Components of Effective Reading Instruction.' Scientific Studies of Reading 1 (3): 187-9.

Murakami, Kayoko. 2017. 'Developing English Phonological Awareness in Elementary School: Focusing on Rhyme and Syllable.' JASTEC Journal 36:1-14.

Murakami, Kayoko, and Atsuko Cheang. 2017. 'Introduction of Phonological Awareness to Japanese Elementary School Students (2): The Explicit Instructions in Syllable Awareness and its Achievement after a Year.' https://www.kobe-yamate.ac.jp/library/journal/pdf/college/kiyo6o/ 6omurakami_cheang.pdf

Nagy, William, E., and Richard Anderson. 1995. Metalinguistic Awareness and Literacy Acquisition in Different Languages. Champaign: University of Illinois at Urbana-Champaign Library.

Nation, Paul. 2001. Learning Vocabulary in Another Language. Cambridge: Cambridge University Press.

National Research Council. 1998. Preventing Reading Difficulties in Young Children. Washington, DC: The National Academies Press. 
Paulson, Lucy H., and Louisa C. Moats. 2010. LETRS for Early Childhood Educators. Longmont: Cambium Learning Sopris West.

Pečjak, Sonja. 1999. Ali slišiš - ali vidiš? Priročnik z vajami za razvoj metajezikovnega zavedanja. Trzin: Izolit.

Phillips, Beth M., Jeanine Clancy-Menchetti, and Christophr J. Lonigan. 2008. 'Succesful Phonological Awareness Instruction.' Topics in Early Childhood Special Education 28 (1): 3-17.

Qian, David D. 2002. 'Investigating the Relationship Between Vocabulary Knowledge and Academic Reading Performance: An Assessment Perspective.' Language Learning 52 (3): 513-36.

Rocha de Souza, Lourdes Bernadete, and Aline Gisele Conceição Leite. 2014. 'Profile of Phonological Awareness in Bilingual and Monolingual Children.' CODAS 26 (1): 61-7.

Sabo, Leon. 2016. 'Izbrani primeri interferenc v slovenščini pri rojenih govorcih ruščine.' Filološke studije 2:226-39.

Schuele, Melanie, and Donna Boudreau. 2008. 'Phonological Awareness Intervention: Beyond the Basics.' Language, Speech, and Hearing Services in Schools 39 (1): 3-20.

Seymour, Philip H. K., Mikko Aro, and Jane Erskine. 2003. 'Foundation Literacy Acquisition in European Orthographies.' British Journal of Psychology 94 (2): 143-74.

Sila, Anita. 2018. 'Pomen sistematičnega razvijanja sposobnosti fonološkega zavedanja pri učenju tujega jezika v predšolskem obdobju.' PhD dissertation, University of Primorska.

Skela, Janez, Urška Sešek, and Mateja Dagarin Fojkar. 2009. 'Opismenjevanje v tujem/drugem jeziku na zgodnji stopnji.' In Učenje in poučevanje dodatnih jezikov v otroštvu, edited by Karmen Pižorn, 26-62. Ljubljana: Zavod Republike Slovenije za šolstvo.

Sparks, Richard L., Jon Patton, Leonore Ganschow, Nancy Humbach, and James Javorsky. 2006. 'Native Language Predictors of Foreign Language Proficiency and Foreign Language Aptitude.' Annals of Dyslexia 56:129-60.

Spencer, Ken. 2007. 'Predicting Children's Word-spelling Difficulty for Common English Words from Measures of Orthographic Transparency, Phonemic and Graphemic Length and Word Frequency.' British Journal of Psychology 98:305-38.

Stahl, Steven A., and Marilyn M. Fairbanks. 1986. 'The Effects of Vocabulary Instruction: A Model-Based Meta Analysis.' Review of Educational Research 56 (1): 72-110.

Sun Alperin, Kendra M., and Min Wang. 2011. 'Cross-Language Transfer of Phonological and Orthographic Processing Skills from Spanish L1 to English L2.' Reading and Writing: An Interdisciplinary Journal 24 (5): 591-614.

Torgesen, Joseph. 1997. 'The Prevention and Remediation of Reading Difficul- 
ties: Evaluating What We Know from Research.' Journal of Academic Language Therapy 1:11-47.

- 2000. 'Individual Differences in Response to Early Interventions in Reading: The Lingering Problem of Treatment Resisters.' Learning Disabilities Research \& Practice 15 (1): 55-64.

Trehearne, Miriam P. 2003. 'Phonological Awareness II.' In Comprehensive Literacy Resource for Kindergarten Teachers, edited by Miriam Trehearne, Lynne Hemming Healy, Maria Cantalini, and Joan L. Moore, 116-154. Vernon Hills, IL: ETA/Cuisenaire.

Treiman, Rebecca, Victor Broderick, Ruth Tincoff, and Katiuska Rodriguez. 1998. 'Children's Phonological Awareness: Confusions Between Phonemes That Differ Only in Voicing.' Journal of Experimental Child Psychology 68 (1):3-21.

Whitehurst, Grover J., and Christopher Lonigan. 2002. 'Child Development and Emergent Literacy.' Child Development 69 (3): 848-72.

Wise, Nancy, and Xi Chen. 2010. 'At-Risk Readers in French Immersion: Early Identification and Early Intervention.' Canadian Journal of Applied Linguistics 13 (2): 128-49.

Yelland, Gregory, Jacinta Pollard, and Anthony Mercuri. 1993. 'The Metalinguistic Benefits of Limited Contact with a Second Language.' Applied Psycholinguistics 14 (4): 423-44.

Yeung, Susanna S., Linda S. Siegel, and Carol K. Chan. 2013. 'Effects of a Phonological Awareness Program on English Reading and Spelling among Hong Kong Chinese ESL Children.' Reading and Writing 26 (5): 681-704.

Yopp, Hallie Kay, and Ruth Helen Yopp. 2000. 'Supporting Phonemic Awareness Development in the Classroom.' The Reading Teacher 54 (2): 130-43.

Ziegler, Johannes C., and Usha Goswami. 2005. 'Reading Acquisition, Developmental Dyslexia, and Skilled Reading Across Languages: A Psycholinguistic Grain Size Theory.' Psychological Bulletin 131 (1): 3-29.

Zorman, Anja. 2007. 'Prepoznavanje glasov in spoznavanje njihovih pisnih ustreznic v maternem in drugem oziroma tujem jeziku.' PhD dissertation, University of Ljubljana. 